\title{
THE APPLICATION OF INTERNET IN ELECTORAL PROCEDURES: A THEORETICAL PERSPECTIVE. THE CASE OF E-VOTING
}

From the second half of the $19^{\text {th }}$ century on, the rapid development of various tools based on electricity commenced. As early as the 1970s, the world saw the so-called "digital revolution" generally understood as the change from the mechanical and electronic technologies to the high tech, digital ones. ${ }^{1}$ The expansion of telecommunication and the progress of the electronic media constitute this period's the stepping stones. The recent worldwide convergence of telecommunication and information technologies (ICT) as well as the dynamic development of mass media have led to noticeable changes in the functioning of contemporary countries and societies. Currently, modern technologies are playing more and more important role and are filtering down to almost every field of contemporary human life. These processes result in the growth of online interactions observed by the inconceivably increased number of people with home PC and Internet access. We say that we are living in the Internet era where anyone who fails to jump on the technology bandwagon is going to be left far behind ${ }^{2}$.

Also, wide access to information (which is much greater thanks to ICT) is becoming increasingly important in social, economical and cultural life. One good demonstration of it is undoubtedly the emergence and use of the concepts such as e-society, e-banking, e-services, e-government, e-government, and e-democracy. The newly used word e-democracy evidences modern technologies to

* dr hab. Małgorzata Musiał-Karg, Wydział Nauk Politycznych i Dziennikarstwa, Uniwersytet im. Adama Mickiewicza, e-mail:magda.musial@interia.pl.

1 K. Rostiashvili, "Information Society and Digital Democracy - Theoretical Discourse." The 11th Scientific Journal in Humanities No. 1 (1), 2012: 11.

2 A. Rubin, "Security Considerations for Remote Electronic Voting over the Internet," http://avirubin.com. Accessed: 12.01.2015. 
be widely used in politics as well. In this context one should bear in mind that, in most countries politicians, political parties and those working in political institutions or administration seek to employ and use new technologies in the processes of informing and communicating with the electorate. The above mentioned political subjects aim to implement ICT in the processes of transmitting and obtaining information. In addition, in many modern countries the traditional voting methods are supplemented with new solutions based on the use of electronic tools.

This text aims at analyzing electronic voting (e-voting) as one of the important forms of electronic democracy. The article attempts to answer several research questions. First, what is the impact of ICT on the voting procedures? Secondly, what is the essence of electronic voting and what are its main features? Last but not least, what are advantages and fears related to the e-voting systems?

This paper gives a theoretical overview of the electronic democracy and voting; of their essence, characteristics, goals. The author tries to present and critically assess the main drawbacks and problems of the existing e-voting systems. The theoretical framework of considerations is based mainly on the concept of the electronic democracy as created by Martin Hagen. With regard to the electronic voting, the author of this article uses definitions given either by the International Institute for Democracy and Electoral Assistance, or by the Competence Center for Electronic Voting and Participation. She also uses the definitions constructed by Andrzej Kaczmarczyk, an e-voting expert.

\section{Electronic democracy as a new paradigm of democratic government}

The swift progress and expansion of ICT influences contemporary societies changing the character of interpersonal relationships, ways of communication, going in for politics as well as contributes to the creation of a new quality of social life. The Information and Communication Technologies has become a tool for politics. The role of ICT has become so important that it pushed some theoreticians of democracy to state the necessity of changing the existing paradigm of understanding a democratic system and introducing the notion of electronic democracy (e-democracy). ${ }^{3}$ The concept of e-democracy is related to the utilization of technology in order to increase participation in power exercising. Some of the first deliberations concerning the links between new technologies and democracy

\footnotetext{
3 B.N. Hague, B. Loader. Digital Democracy: Discourse and Decision-making in the Information Age. New York: Routledge 1999.
} 
reflected the potential of telecommunications, with particular emphasis on cable TV and telephone. ${ }^{4}$ Today the focus has shifted to the Internet whose role is growing rapidly. ${ }^{5}$ ICT now makes it possible for citizens to participate in the process of public life creation. An increased access to information and to political debate, online political discussions and new additional forms of voting (e-voting) constitute the main aspects of electronic democracy. Such an electronic republic may be a great "opportunity for citizens to elect representatives, while increasingly being able to participate in law making. ${ }^{6}$

In social studies there is no agreement as to the understanding of the term electronic democracy, thus there is no uniform definition of the term, either. It is worth, though, to present a couple of explanations most distinctive and accurate for the proper understanding of the term. In the document entitled Inquiry into Electronic Democracy. Final Report by Australian Parliament of Victoria Electronic democracy is defined as: "The use of information communications technologies by individuals to extend their choices for thinking and acting as citizens, unrestricted by time and place, and culminating in greater collective freedoms under rule of law."

Issues related to electronic democracy are examined by Polish scholars (e.g. M. Grabowska, T. Szawiel, A. Kaczmarczyk, M. Sakowicz, M. Nowina-Konopka). According to definition presented by Andrzej Kaczmarczyk and Roman Czajkowski, electronic democracy refers to a set of processes realized through electronic. The processes encompass researching activities, planning, implementation and management (making decisions, taking control, information, communication and more). The authors maintain that owing to the information society,

4 T. Carrizales, "Critical Factors in an Electronic Democracy: a Study of Municipal Managers." The Electronic Journal of e-Government Vol. 6, Iss. 1, 2008: 24, www.ejeg.com/volume-6/vol6-iss1/Carrizales.pdf. Accessed: 27.02.2010; F.Ch. Arterton, "Political Participation and Teledemocracy." Political Science and Politics. Vol. 21, No. 3, 1988: 620-626; Th.L. Becker, Ch.D. Slaton. The Future of Teledemocracy. Westport CT: Praeger Publishers 2000.

5 T. Carrizales, op.cit., p. 24.

$6 \quad$ L.K. Grossman, The Electronic Republic: Reshaping Democracy in the Information Age. New York: Penguin Books 1995.

7 "Inquiry into Electronic Democracy. Final Report." Parliament of Victoria, Australia, Scrutiny of Acts and Regulations Committee, 2003: xliv, www.parliament.vic.gov.au. Accessed: 14.01.2015. 
a new model of democracy will be created. E-democracy will be based on information and communication application. ${ }^{8}$

According to Martin Hagen, ,an Electronic Democracy is any democratic political system in which computers and computer networks are used to carry out crucial functions of the democratic process - such as information and communication, interest articulation and aggregation, and decision-making (both deliberation and voting)." Hagen lists three various concepts of electronic democracy: teledemocracy, cyberdemocracy and electronic democracy.

Teledemocracy developed in the 1970s and was designed both to introduce additional forms of direct democracy within the American political system and implement these forms using new communication technologies. Whereas the concept of teledemocracy has emerged as a result of the cable television development, cyberdemocracy has been dependant on the evolution of computer networks. Unlike teledemocracy and cyberdemocracy, electronic democratization does not aim at establishing direct forms of democracy but rather at improving the representative democracy. ${ }^{10}$ Hagen understands electronic democratization as a form of democracy development and reinforcement by way of using new communication technologies to strengthen the political power of those who are often omitted in the most important political processes. ${ }^{11}$ Electronic democratization goes in line with representative forms of democracy and emphasizes the value both of information exchange and political discussions for the citizen involvement in the political sphere.

Taking into account the political market structure one may list three main processes that occur there: informing, communicating and voting. Besides their traditional dimension, the development of new technologies contributed to the emergence of new ways of those practices. The growth of online interaction and presence can be demonstrated by the exponential increase in the number of peo-

8 A. Kaczmarczyk, R. Czajkowski. "E-Głosowanie - niezbędny element elektronicznej platformy do obsługi procedur w demokracji w społeczeństwie informacyjnym". ["E-Vote - an Essential Element of Electronic Platform for Services for Democratic Procedures in the Information Society.”] The paper presented at the conference entitled „Tworzenie mechanizmów i struktur rozwoju elektronicznej gospodarki w Polsce" held in Warsaw on 12.06.2001: 48, www.logistyka. net.pl/images/articles/1375/Ref-Czajkowski.doc. Accessed: 13.12.2014.

9 M. Hagen, "A Typology of Electronic Democracy" 1997, www.martin-hagen.net/pub/ typology.html. Accessed: 16.01.2015.

10 Ibidem.

11 K.L. Hacker, M. Todino. "Virtual Democracy at the Clinton White House: An Experiment in Electronic Democratisation." javnost/the public Vol. 3, No 1, 1996: 72. 
ple with home computers and Internet access. ${ }^{12}$ ICT, and most of all, the Internet, influence democratic processes thus supplementing, quickening and facilitating the processes of information sharing, the involvement in political debate and the participation in political decision-making. ${ }^{13}$

Electronic democacracy is oftentimes called digital democracy, which, in turn and according to Ketevan Rostiashvili, is referred to as a new level of democracy, a framework for the Information Society. Rostiashvili states that:

digital democracy has become a leading system of the political, social, economic and cultural functioning of the Information Society...Digital Democracy presents a symbiosis of electronic technologies, its developments in digital data transferred into ICT in use of millions of people and nations. Digital Democracy interacts among people, parties, governments, business, local communities and social networks. Digital Democracy as the new ICT applications emerged out of the "dialectical interaction between technology and society." 14

On the other hand, according to definitions by Ken Hacker and Jan van Dijk, digital democracy is "a collection of attempts to practice democracy without the limits of time, space and other physical conditions, using ICT or CMC (Computer-mediated Communication), as an addition, not a replacement for traditional 'analogue' political practices." ${ }^{15}$ Consequently, digital democracy combines representative and direct democracy, with more and more power transferred to the people who use ICT. ${ }^{16}$

Advocates of digital form of democracy assert that, thanks to the new technologies that enable people to overcome the barriers of time and place, those eligible to participate in political life may communicate and take political decisions (elections, referenda) via the Internet. This feature of digital democracy is considered very important as resulting from the assumption that such a democratic form may cure the ills of modern democracy. ${ }^{17}$ On the other hand, some theoreticians believe that the new technologies have no potential to "fix a lack of

12 A. Rubin, op.cit., p. 1.

13 R. Tsagarousianou, "Electronic Democracy: Rhetoric and Reality, Communications." The European Journal of Communication Research Vol. 24, No. 2, 1999: 189-208.

14 K. Rostiashvili, op.cit., p. 12; M. Castells, The Rise of the Network Society, Vol. 2: The Power of Identity, Oxford: Blackwell 2009: 5.

15 Digital Democracy: Issues of Theory and Practice. Eds. K.L. Hacker, I. Dijk, London 2000: 1 .

16 M. Castells, op.cit., p. 6.

17 L.K. Grossman, op.cit. 
political will, knowledge, experience, motivation and skills required for full participation in various democratic activities. No technology can dissolve the social and material inequalities that appeared to be so strongly related to differences of electoral process and political participation process." ${ }^{18}$ The opinion is related to the fact that individuals' ability to benefit from the Internet varies significantly across the world. The "'digital divide' is the latest evocative term that refers to differences in the access to and uses of information technology correlated with income, race and ethnicity, gender, age, place of residence, and other measures of socioeconomic status." ${ }^{\prime 19}$ The digital divide is thus understood as a gap between individuals, households, businesses and geographic areas at different socio-economic levels with regard both to these units' opportunities to access information and communication technologies (ICT) and the use of Internet for a wide variety of activities. ${ }^{20}$ Thus, although modern technologies play an important role in contemporary political life, we should bear in mind that democracy is still lacking in real public participation as a collaborative main actor in decision-making processes. This skeptical attitude toward the role of information and communication technologies as regards democracy is reinforced by the arguments "that much of the use being made of ICT with in local communities has little bearing on the goals of re/engaging people in politics and strengthening the democratic process." 21

The discussion about the new paradigm of democracy pushes many researchers to consider electronic voting, the most important instrument of e-democracy.

\section{E-voting as a new way of participating in popular votes}

E-democracy is related to making use of the opportunities that ICT offers in order to strengthen democracy, democratic institutions and the democratic process. ${ }^{22}$ Of all the e-democratic devices, electronic voting in particular is getting

18 K. Rostiashvili, op.cit., p. 13; P. Levine, "Can the Internet Rescue Democracy? Toward an On-line Commons". Democracy's Moment: Reforming the American: Political System for the 21st Century. Eds. R. Hayduk, K. Mattson. Lanham: Rowman \& Littlefield 2002: 121-137.

19 R.G. Noll, D. Older-Aguilar, G. Rosston, R.R. Ross, The digital Divide: Definitions, Measurement, and Policy Issues, http://faculty.chicagobooth.edu/austan.goolsbee/teaching/digdiv.pdf. Accessed: 16.01.2015.

20 Understanding the Digital Divide. OECD. Paris 2001: 5.

${ }^{21}$ K. Rostiashvili, op.cit., p. 13.

22 "Council of Europe Activities in the Field of e-democracy," www.coe.int/t/dgap/democracy/Activities/GGIS/CAHDE/Default_en.asp. Accessed: 15.01.2015. 
more and more attention worldwide. Politicians and authorities of many countries are interested in e-voting possibilities and conduct experiments to introduce this new form of voting. Additionally, more and more countries are eager to make use of electronic way of expressing their opinions in voting procedures. ${ }^{23}$

Undoubtedly, electronic voting is a subject of increasing interest as regards public administration institutions, parliaments, governments, political parties, politicians, academics or journalists. Also, e-voting seems to be gaining in significance and is becoming one of the primary instruments of e-democracy. Numerous researchers working on processes based on the application of new technologies in politics assert that in the future citizen's rights and duties will be realized via information and communication technologies. Electronic voting, currently implemented in an increasing number of countries comprises an essential element of such an expansion.

According to definition by Czajkowski and Kaczmarczyk, "electronic voting... is the act of voting with the use of electronic means. Electronic voting comprises computer voting - which in turn comprises online voting, and internet voting which requires computer with an access to the Internet." 24

With regard to the differentiation of voting forms that use ICT (information and communication technologies), an obvious lack of terminological discipline can be observed in the literature on the subject. According to another definition, electronic voting (e-voting) is an election system that allows an eligible voter to record his or her secure and secret ballot electronically. E-voting is a term encompassing several different types of voting, embracing the electronic means both of casting a vote and counting votes. The electronic voting technology can include punch cards, optical scan voting systems and specialized voting kiosks. It can also involve transmission of ballots and votes via telephones, private computer networks, or the Internet. This understanding of e-voting is confirmed in the definition by the Competence Center for Electronic Voting and Participation. The CCEV\&P offers stating that, in a broader sense, electronic voting equals to

23 In the Netherlands, $62 \%$ of the people with access to the Internet would prefer to vote online. W. Pieters, M.J. Becker. "Ethics of e-Voting. An Essay on Requirements and Values in Internet Elections," www.win.tue.nl/ipa/archive/falldays2005/Paper_Pieters.pdf. Accessed: 15.01.2015. M. Musiał-Karg, Elektroniczne referendum w Szwajcarii. Wybrane kierunki ewolucji helweckiej demokracji bezpośredniej. Poznań: Wydawnictwo Wydziału Nauk Politycznych i Dziennikarstwa UAM 2012: 72-78.

24 A. Kaczmarczyk, R. Czajkowski, op.cit., p. 47, 50. 
the use of electronic means in one of the following three processes: identification of voters, casting the vote, and counting the vote. ${ }^{25}$

In the discussion on new ways of citizen's participation in democratic procedures two types of voting are usually mentioned: electronic voting (e-voting) and internet voting (i-voting). While $e$-voting is a broad term encompassing other electronic voting techniques, $i$-voting is but one of its forms and refers to the remote Internet voting. It needs to be highlighted that many observers and commentators of public life are generally optimistic about the potential possibilities of $i$-voting. Advocates of $i$-voting seem to believe that it has a potential to solve the currently noticeable problem of low voter turnout by providing a more convenient option. Opponents of $i$-voting argue, on the other hand, that the biggest challenge of i-voting systems is security risks and that " $i$-voting will disproportionately benefit certain groups based on race and economic status."26

\section{Electronic voting (e-voting) \\ term of broader meaning \\ - refers to technologies that are used within voting processes such as: digital broadcasting, telephony, the Internet.}

Internet Voting at the

Polling Place

- voting is conducted in a previously prepared place that has a connection to the Internet

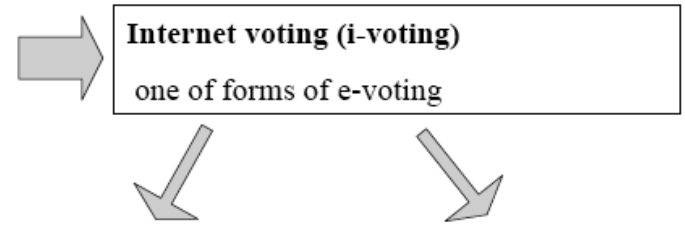

\section{Remote Internet Voting}

- remote way of voting which enables a voter to vote from a "voting booth" or through a home PC that is connected to the Internet.

Diagram 1. Electronic voting and its forms

Source: The Author's own current research based on M. Nowina-Konopka 2006.

25 Competence Center for Electronic Voting and Participation, www.e-voting.cc/en/it-elections/definitions. Accessed: 20.01.2014.

26 B. Stohs, “Is I-voting Illegal?": 2, www.law.duke.edu/journals/dltr/articles/pdf/ 2003DLTR0013.pdf. Accessed: 15.01.2015. 
The term "electronic voting" refers to the technologies used within voting processes such as digital broadcasting, telephony, or the Internet. ${ }^{27}$ Internet voting is divided into two categories: the Internet Voting at the Polling Place and the Remote Internet Voting. The first form is based on the voting conducted in a previously prepared place with an Internet connection, while the second comprises a remote way of voting enabling the voter to vote from a "voting booth" or via their Internet-connected home PC. Both the booth and the PC data is transmitted online to a central database.

Considering the essence of e-voting one has to emphasize that this form of participation has been the subject of significant interest of the Committee of Ministers of the Council of Europe. Adopted in 2004, the Council of Europe Recommendation $\operatorname{Rec}(2004) 11^{28}$, states on the legal, operational and technical standards for e-voting, and is one of the first regulatory efforts in the said area, so far the only one at the international level. Its ambition is to map up legal principles for democratic elections with the e-voting-specific operational and technical requirements. ${ }^{29}$ In the narrow understanding, e-voting is treated as a use of electronic means (ICT) in at least the vote-casting.

As stated before, Internet voting constitutes an e-voting form. The Internet voting - or online voting - is often described as remote electronic voting, for it refers to the possibility to cast an Internet vote. Such a vote is cast in an uncontrolled environment. ${ }^{30}$

Another form of electronic voting is so called "Kiosk Voting". This way of e-voting is understood as the electronic casting of the vote outside of a polling station in an uncontrolled environment on a voting computer:

Electronic voting machines of EVMs are used in the polling station. The vote is cast on a touch-sensitive screen of a voting computer or via a keyboard. Some EVMs provide the voter with a paper receipt of the cast vote. Optical Scan-

27 M. Nowina-Konopka. "Elektroniczna urna.” 2006: 2, www.rpo.gov.pl/pliki/ 12066058070.pdf. Accessed: 11.02.2010.

28 "Recommendation Rec(2004)11 of the Committee of Ministers to Member States on Legal, Operational and Technical Standards for e-Voting Adopted by the Committee of Ministers on 30 September 2004 at the 898th Meeting of the Ministers' Deputies," www.coe.int/t/DEMOCRACY/ELECTORAL-ASSISTANCE/themes/evoting/Rec-2004-11_en.pdf. Accessed: 13.01.2015.

29 A.D. Maurer, "Ten Years Council of Europe Rec(2004)11. Lessons Learned and Outlook." The $6^{\text {th }}$ International Conference on Electronic Voting EVOTE2014, 28-31 October 2014, Lochau/Bregenz, Austria. Ed. R. Krimmer, M. Volkamer. Tallinn: TUT Press: 111, www.e-voting.cc/wp-content/uploads/downloads/2014/10/EVOTE2014_Proceedings_Web.pdf. Accessed: 13.01.2015.

30 "Definitions." Competence Center for Electronic Voting and Participation, www.e-voting.cc/en/it-elections/definitions. Accessed: 13.01.2015. 
ning Machines or OSM are scanning the ballot paper. After the successful scanning, the vote is counted electronically but the paper ballots are still present for a possible manual recount. Some OSM devices display the scanned results to the voter and ask for her/his confirmation before storing the electronic vote. ${ }^{31}$

As there exist many different solutions and ways of using technologies in the electoral procedures at different their stages, also electronic registration and electronic counting procedures require mentioning. The electronic voter registration takes place when voters are registered via the electronic channel procedure, whereas the electronic counting or e-counting refers to the use of electronic tools in vote counting.

From the technical point of view, e-voting systems consist of six main stages. The first stage consists of voters' registration; a phase aimed both at voterdefining for the e-voting system and giving them the authentication data to log into the system. The second phase is authentication. It rests on the verification of voters' access rights and franchise. After the authentication phase, the voting and the votes' saving stage follows. In this phase eligible voters cast votes, while the e-voting system saves their received votes. The vote-managing phase is a process of managing and sorting votes so as to prepare them for counting. The fifth phase - votes' counting - aims at decrypting and counting votes in order to output the final tally. The last stage of electronic voting is the auditing based on checking whether the eligible voters were capable to vote as well as whether their votes can participate in the computation of final tally, also occurring at this stage of e-voting. ${ }^{32}$

\section{Advantages of electronic voting}

Before assessing the possible role of electronic voting, we must consider e-voting systems for their attractiveness and general significance. While not exhaustive, the following section summarizes some of the vital issues as raised by the electoral authorities, administration officers, or politicians with respect to electronic voting.

31 Ibidem.

32 A. Buldas, T. Mägi, "Practical Security Analysis of E-voting Systems." Advances in Information and Computer Security. Second International Workshop on Security, IWSEC 2007, Nara, Japan, October 29-31, 2007. Proceedings. Ed. A. Miyaji, K. Kikuchi, K. Rannenberg. Berlin: Springer 2007. 
There is no doubt that the popularity of electronic voting is growing, mainly because it is a novel concept to hundreds of millions of people worldwide - and because many voters prefer $e$-voting (in particular online voting) to any other voting method. ${ }^{33}$

Enabling citizens to vote and decide directly about important matters of concern to societies lies at the heart of democracy. ${ }^{34}$ One cannot but keep emphasizing that electronic voting is not intended to replace the traditional way of voting. The primary purpose of employing ICT is providing an alternative increasing the accessibility to the voting process for a wider variety of citizens, the disabled, those living or working abroad or in remote areas, and immigrant citizens included.

In comparison to other voting techniques, electronic voting systems do offer advantages. Taking into consideration the voting procedures alone, one can affirm that the revolution in new technologies has affected the management of the election process in a number of ways. The most important advantage of e-voting is that it can be involved in any one of a number of steps in the setup, distributing, voting, collecting, and counting of ballots. "Electoral authorities use computer systems to make their internal management and communications more effective, to systematize voter registration records, and to communicate with voters, among other tasks. ${ }^{\prime 35}$

Proponents of the electronic voting have argued that it can increase the voter turnout, cause it enables to vote those disabled or those who are staying abroad. The e-voting is more convenient than the traditional voting at the polling station as well - there is no longer a need to leave home and travel to a given institution, no need to wait in queues. This new form of vote-casting can be very profitable when it comes to the turnout. E-voting influences the participation level because it appeals to younger voters among whom the voter turnout has tended to be particularly low. What is more, many supporters of e-voting (in particular online voting) claim that it allows for wider proliferation of information about candidates, political parties, their programs and policies. However, it should be born in mind that using the Internet for campaigning in certain countries "would be in conflict with existing laws about not campaigning in the immediate vicinity of

33 „The I's Have It,” www.everyonecounts.com/index.php/why_everyone_counts/why_ivoting. Accessed: 14.02.2010.

34 S. Grabowska, Instytucja ogólnokrajowej inicjatywy ludowej w wybranych państwach europejskich. Studium prawno-porównawcze. Rzeszów: Wydawnictwo Uniwersytetu Rzeszowskiego 2005: 18.

35 J. Blanc, "Challenging the Norms and Standards of Election Administration: Electronic Voting." Challenging the Norms and Standards of Election Administration. IFES 2007: 11. 
a polling place and would need to be strictly supervised." ${ }^{36}$ Electronic voting can also be a very cost-saving method. In the long run it reduces expenses involved in the poll site setting up and staffing. It needs to be highlighted that in the initial phase of voting arrangements, e-voting can generate relatively high expenditures as regards the new system infrastructure.

\section{Concerns about electronic voting}

The process of introducing new forms of the democratic procedure has provoked the discussion of the e-voting shortcomings. Even though societies widely apply modern technologies (mainly Internet) to business, work or education, governments and legislative bodies as well as politicians, experts and academics in many countries continue using ICT in voting procedures with care. One example can be the several countries having expressed their concern over the possibility of electronic voting leading to a massive electoral fraud. Also, the transparency of the election process has been question as "all processes of data generation, transformation, and storage occur in 'black boxes' that are often not fully transparent even for technical experts." ${ }^{\prime 37}$ That is why electronic voting system is sometimes referred to as the "black box" - voters, candidates and even officials cannot see through the "inner" workings of the election machine. Only a small group of technologists (system administrators) and other experts does have an idea about voting-conducting or vote-counting. Discussing the pros and cons of e-voting, its opponents keep asking the question of whether voters should trust a computer? This question is more often asked by the part of society without Internet access unable to enjoy the convenience of e-voting, or, like the older generation, feeling uncomfortable using the system. The "internet fear" therefore divides societies into the skilled and knowledgeable citizens on the one hand, and those worse equipped and unskilled on the other to the degree that it can eventually result in a growing participation gap. This phenomenon is known as the "digital divide;" an important issue reinforcing welfare differences in geographical regions.

A very significant concern about e-vote is voters' authentication. Because today there exist few universally available forms of digital identification, it is practically impossible to ensure that those voting remotely over the Internet are

36 Online Voting, Parliamentary Office of Science and Technology, Postnote no 155/2001, p. 3, www.parliament.uk/post/pn155.pdf. Accessed: 11.02.2010.

37 J. Gerlach, U. Gasser, Three Case Studies from Switzerland: E-Voting. Berkman Center Research Publication No. 03.1, 2009: 5. 
really who they say they are. On one hand, passwords and digital signatures come to aid, but on the other - they can be shared among voters, too. Technical problems is not an unheard of shortcoming of the electronic voting system. The voting systems based on ICT are vulnerable to attacks both on the central e-voting servers and on each voter's private computer. These attacks can eventuate in the disruption of the voting process and bring the final results of voting into question. That is why servers, systems, computers, or kiosks should be secured against being tampered with or infected with viruses. ${ }^{38}$ Many countries have resigned from $e$-voting because they find it too risky. Other nations do not seem to realize the advantages of the electronic voting over the traditional, i.e. ballot box elections.

\section{Conclusions}

The contemporary democracy is changing. The application of ICT has contributed to the emergence of the notions of electronic democracy, digital democracy, e-voting. The names of these new forms and tools of democracy suggest the change of the democratic government paradigm. Without any doubt, electronic voting (e-voting) represents a significant challenge for modern democracies. This new form of the election- and referendum participation has the potential to facilitate and improve electoral processes and has been adopted in many countries, for a number of reasons. Its main advantages as listed by e-voting supporters are: the increased voter access, possibility of decreased costs (in the long term perspective), earlier announcement of results, potentially fewer opportunities for retail fraud, and fewer errors by voters and poll workers. These technologies, however, pose some risks (the possibility of technical failure, external interference with the system, loss of accountability of the election management bodies etc.)

\section{WORKS CITED}

Arterton, Christopher F. "Political Participation and Teledemocracy." Political Science and Politics Vol. 21, No 3, 1988.

Becker, Theodore L., Christa Daryl Slaton. The Future of Teledemocracy. Westport: Praeger CT 2000. 
Blanc, Jarrett. "Challenging the Norms and Standards of Election Administration: Electronic Voting." Challenging the Norms and Standards of Election Administration. IFES 2007.

Buldas, Ahto, Triinu Mägi. "Practical Security Analysis of E-voting Systems." Advances in Information and Computer Security. Second International Workshop on Security, IWSEC 2007, Nara, Japan, October 29-31, 2007. Proceedings. Ed. A. Miyaji, K. Kikuchi, K. Rannenberg. Berlin: Springer 2007.

Carrizales, Tony. "Critical Factors in an Electronic Democracy: a Study of Municipal Managers." The Electronic Journal of e-Government Vol. 6, Iss. 1, 2008, www. ejeg.com/volume-6/vol6-iss1/Carrizales.pdf. Accessed: 27.02.2010.

Castells, Manuel. The Rise of the Network Society. Vol. 2: "The Power of Identity." Oxford: Blackwell 2009.

Competence Center for Electronic Voting and Participation, www.e-voting.cc/en/it-elections/definitions. Accessed: 20.01.2014.

Council of Europe activities in the field of democracy, www.coe.int/t/dgap/democracy/ Activities/GGIS/CAHDE/Default_en.asp. Accessed: 15.012015.

Gerlach, Jan, Urs Gasser. Three Case Studies from Switzerland: E-Voting. Berkman Center Research Publication No. 03.1, 2009.

Grabowska, Mirosława. Instytucja ogólnokrajowej inicjatywy ludowej w wybranych państwach europejskich. Studium prawno-porównawcze, Rzeszów 2005.

Grossman, Lawrence K. The Electronic Republic: Reshaping Democracy in the Information Age. New York 1995.

Hacker, Kenneth L., Jan van Dijk (eds.). Digital Democracy: Issues of Theory and Practice. London: SAGE 2000.

Hacker, Kenneth L., Michael Todino. "Virtual Democracy at the Clinton White House: An Experiment in Electronic Democratisation." javnost/the public Vol. 3, No. 1, 1996.

Hagen, Martin. A Typology of Electronic Democracy 1997, www.martin-hagen.net/pub/ typology.html. Accessed: 16.01.2015.

Hague, Barry N., Brian Loader. Digital Democracy: Discourse and Decision-making in the Information Age. New York: Routledge 1999.

Inquiry into Electronic Democracy. Final Report. Parliament of Victoria, Australia, Scrutiny of Acts and Regulations Committee 2003, www.parliament.vic.gov.au. Accessed: 14.01.2015.

Kaczmarczyk, Andrzej, Roman Czajkowski. „E-Głosowanie - niezbędny element elektronicznej platformy do obsługi procedur w demokracji w społeczeństwie informacyjnym.” [,E-vote - an Essential Element of Electronic Platform for Services for 
Democratic Procedures in the Information Society."] The paper presented at the conference entitled „Tworzenie mechanizmów i struktur rozwoju elektronicznej gospodarki w Polsce.” Warszawa 12.06.2001, www.logistyka.net.pl/images/articles/1375/Ref-Czajkowski.doc. Accessed: 13.12.2014.

Levine, Peter. "Can the Internet Rescue Democracy? Toward an On-line Commons." Democracy's Moment: Reforming the American Political System for the 21st Century. Ed. R. Hayduk, K. Mattson. Lanham: Rowman \& Littlefield 2002.

Maurer, Ardita Driza. "Ten Years Council of Europe Rec(2004)11. Lessons learned and Outlook." $6^{\text {th }}$ International Conference on Electronic Voting EVOTE2014, 28-31 October 2014, Lochau/Bregenz, Austria. Ed. R. Krimmer, M. Volkamer. Tallin: TUT Press 2014, www.e-voting.cc/wp-content/uploads/downloads/2014/10/EVOTE2014_Proceedings_Web.pdf. Accessed: 13.01.2015.

Musiał-Karg, Magdalena. Elektroniczne referendum w Szwajcarii. Wybrane kierunki ewolucji helweckiej demokracji bezpośredniej. Poznań: Wydawnictwo Wydziału Nauk Politycznych i Dziennikarstwa UAM 2012.

Noll, Roger G., Dina Older-Aguilar, Gregory Rosston, Richard Ross. "The Digital Divide: Definitions, Measurement and Policy Issues," http://faculty.chicagobooth. edu/austan.goolsbee/teaching/digdiv.pdf. Accessed: 16.01.2015.

Nowina-Konopka, Maria. „Elektroniczna urna” 2006, www.rpo.gov.pl/pliki/ 12066058070. pdf. Accessed: 11.02.2010.

O'Hanlon, Charlene. "A Conversation with Douglas W. Jones and Peter G. Neumann." Queue Vol. 4, No. 9, 2006, http://queue.acm.org/detail.cfm?id=1180188. Accessed: 15.01.2015.

“Online Voting." Parliamentary Office of Science and Technology. Postnote No. 155/2001, www.parliament.uk/post/pn155.pdf. Accessed: 11.02.2010.

Pieters, Wolter, Marcel J. Becker. "Ethics of e-Voting. An Essay on Requirements and Values in Internet Elections," www.win.tue.nl/ipa/archive/falldays2005/Paper_Pieters.pdf. Accessed: 15.01.2015.

"Recommendation Rec(2004)11 of the Committee of Ministers to Member States on Legal, Operational and Technical Standards for e-Voting (Adopted by the Committee of Ministers on 30 September 2004 at the 898th Meeting of the Ministers' Deputies," www.coe.int/t/DEMOCRACY/ELECTORAL-ASSISTANCE/themes/evoting/Rec-2004-11_en.pdf. Accessed: 13.01.2015.

Rostiashvili, Ketevan. "Information Society and Digital Democracy - Theoretical Discourse." 11 Scientific Journal in Humanities No. 1 (1), 2012.

Rubin, Avi. "Security Considerations for Remote Electronic Voting over the Internet," http://avirubin.com. Accessed: 12.01.2015. 
Stohs, Brett. “Is i-Voting Illegal?" www.law.duke.edu/journals/dltr/articles/pdf/ 2003DLTR0013.pdf. Accessed: 15.01.2015.

"The I's Have It," http://www.everyonecounts.com/index.php/why_everyone_counts/ why_i-voting. Accessed: 14.02.2010.

Tsagarousianou, Rosa. "Electronic democracy: Rhetoric and Reality, Communications." The European Journal of Communication Research Vol. 24, No. 2, 1999.

Understanding the Digital Divide. OECD, Paris 2001.

\section{Summary}

From the 1970s, the world has been undergoing the so-called "digital revolution" generally understood as the change from the mechanical and electronic technologies to the high tech, digital ones. The role of ICT has so gained in importance that some theoreticians of democracy speak of the necessity of paradigm changing as regards both the understanding of a democratic system and introdu-cing the notion of electronic democracy (e-democracy).

The aim of this text is analyzing the electronic voting (e-voting) as one of important forms of electronic democracy. The article attempts at approaching several research questions. First, what is the impact of ICT on voting procedures? Secondly, what is the essence of electronic voting and what are its main features? Finally, what are the advantages and fears related to e-voting systems?

This paper gives a theoretical overview of the electronic democracy and electronic voting, and demonstrates their essence, characteristics, goals. The author tries to present and critically assess the main drawbacks and problems of the existing e-voting systems. The theoretical considerations framework is based mainly on the concept of electronic democracy created by Martin Hagen. With reference to electronic voting, the author of this article uses definitions as given either by the International Institute for Democracy and Electoral Assistance, or the Competence Center for Electronic Voting and Participation. She also uses definitions constructed by Andrzej Kaczmarczyk, an e-voting expert.

Keywords: electronic democracy, e-democracy, electronic voting, e-voting 
The Application of Internet in Electoral Procedures: a Theoretical Perspective... 93

\title{
WYKORZYSTANIE INTERNETU W PROCEDURACH WYBORCZYCH - PERSPEKTYWA TEORETYCZNA. PRZYPADEK ELEKTRONICZNEGO GLOSOWANIA
}

\begin{abstract}
Streszczenie
Od lat 70. XX wieku współczesna cywilizacja ma do czynienia z tzw. rewolucją cyfrową, rozumianą jako przejście od zastosowania rozwiązań mechanicznych i elektronicznych do najnowszych zaawansowanych technologii informacyjnych i komunikacyjnych. Rola ICT zyskała tak duża wagę, iż niektórzy teoretycy demokracji dostrzegli konieczność zmiany paradygmatu rozumienia systemu demokratycznego, czego efektem było wprowadzenie pojęcia demokracji elektronicznej (e-demokracja).

Przedmiotem niniejszego tekstu jest analiza głosowania elektronicznego (e-głosowania) jako jednego z istotnych instrumentów demokracji elektronicznej. Artykuł jest próbą odpowiedzi na następujące pytania badawcze: Po pierwsze, o wpływ ICT na procedury głosowania. Po drugie, o istotę głosowania elektronicznego oraz jego główne cechy. Wreszcie, o korzyści i wady związane z wdrożeniem systemów e-głosowania.

W tekście dokonano ponadto przeglądu definicji elektronicznej demokracji oraz elektronicznego głosowania, zwracając uwagę na ich istotę, najważniejsze cechy oraz cele.

Teoretyczną podstawę prowadzonych rozważań stanowi przede wszystkim (choć nie tylko) koncepcja demokracji elektronicznej sformułowana przez Martina Hagena. W przypadku głosowania elektronicznego, autorka wsparła się definicjami m.in. Międzynarodowego International Institute for Democracy and Electoral Assistance czy Competence Center for Electronic Voting and Participation, czy Andrzeja Kaczmarczyka, zajmującego się m.in. badaniami nad e-głosowaniem.
\end{abstract}

Słowa kluczowe: elektroniczna demokracja, e-demokracja, elektroniczne głosowanie, e-voting 
